
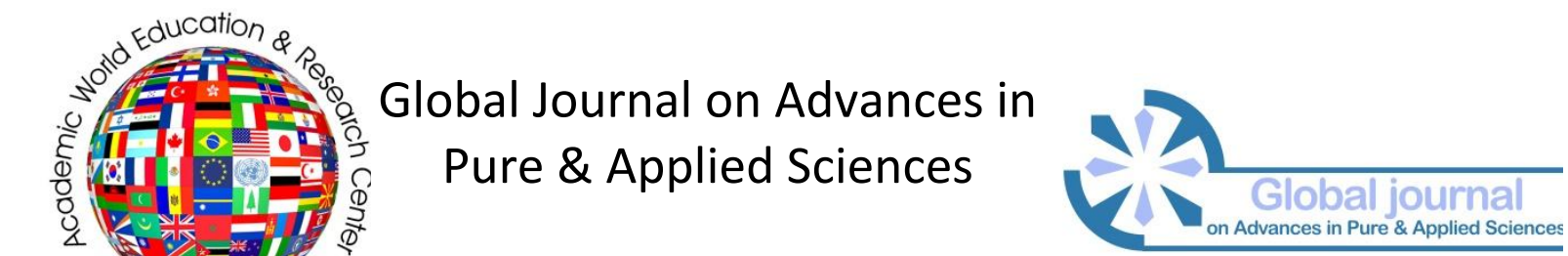

Issue 7 (2016) 57-64

Selected Paper of 2nd World Conference on Health Sciences (H-SCl 2015)

30 April-02 May 2015Efes Surmeli Hotel \& Convention Center - Izmir, Kuşadası, Turkey

\title{
Determination of the satisfaction and motivation levels in a group of nursing students
}

Ilkay Culha ${ }^{*}$,Eskisehir Osmangazi University, Eskisehir School of Health,Eskisehir,Turkey.

Nedime Kosgeroglu, Eskisehir Osmangazi University, Eskisehir School of Health,Eskisehir,Turkey.

Aysun Yılmaz, Eskisehir Osmangazi University, Eskisehir School of Health,Eskisehir, Turkey.

Alaettin Unsal,Eskisehir Osmangazi University,Faculty of Medicine,Eskisehir,Turkey.

\section{Suggested Citation:}

Culha, I., Kosgeroglu, N., Yılmaz, A.\& Unsal, A.(2016). Determination of the satisfaction and motivation levels in a group of nursing students,Global Journal on Advances in Pure \& Applied Sciences.[Online].07, pp 5764.Available from: www.propaas.eu

Received October 07, 2015; revised December 15, 2014; accepted March 16, 2015.

Selection and peer review under responsibility ofProf. Dr. Fahrettin Sadıkoglu, Near East University.

(C)2016Academic World Education \& Research Center. All rights reserved.

\begin{abstract}
Objective: Determine the satisfaction and motivation levels in a group of nursing student who have surgical nursing lesson. Materials and methods: This is a descriptive research carried out between 10-24 March 2014 with 97 students. Personal information form, Student Satisfaction Scale and Motivation Scale were filled by students under observation. The datas were analyzed with IBM SPSS 21 statistical software package. One-way analysis of variance analyzes, Student's t test and Spearman correlation analyzes were used. The statistical significance level was accepted as being $p<0.05$.Findings:Students' satisfaction scores were between 1.72-4.64 with mean of 3.33 \pm 0.55 . There was found difference between satisfaction about department, living within Eskisehir and satisfaction scores ( $p<0.05$ for each one). Students' motivation scores were between 2.07-4.97 with mean of $3.73 \pm 0.52$. There was found difference between gender, whether the department was chosen of the student's own free will and satisfaction from the department ( $p<0.05$ for each one). There was a positive weak correlation between satisfaction and motivation scores of students $(r=0.241, p=0.017)$. Conclusion:Satisfaction about department and living in city center were found effective on students' satisfactions.
\end{abstract}

\footnotetext{
* ADDRESS FOR CORRESPONDENCE: Illkay Culha,Eskisehir School of Health,Eskisehir Osmangazi University,Eskisehir,Turkey E-mail address: ilkayc.ilkay@gmail.com
} 
Culha, I., Kosgeroglu, N., Yılmaz, A.\& Unsal, A. (2016). Determination of the satisfaction and motivation levels in a group of nursing students, Global Journal on Advances in Pure \& Applied Sciences. [Online]. 2015, 07, pp 57-64. Available from: www.propaas.eu

Students' satisfaction and motivation levels should be determined and necessary regulations, improvements should be done.

Keywords: student education, student satisfaction, student motivation.

\section{Introduction}

With the scientific, technical and professional knowledge and skills they provide to students, universities are teaching institutions which play an important role in the scientific, economic, technological and cultural development of communities [23,24]. Thus, in order to be able to keep step with these developments, they periodically need to assess the quality of teaching environment. The study of the satisfaction, attitudes, needs and experiences of students is important in accordance with this aim $[19,23]$.

When it is considered that one of the fundamental objectives of the young is to win a place at university, and of students is to graduate successfully having derived satisfaction from their department and attempt to achieve their expectations from life, the importance of this, both for them and in terms of community life can be seen [23]. The degree to which the expectations of students is met has an impact on both their success and their satisfaction scores. Complaints and dissatisfaction increase when expectations are not met. In general, there is a negative correlation between satisfaction and complaints. The level of satisfaction rises at the rate with which complaints fall, and vice-versa [8]. Therefore, by monitoring current developments, educational institutions and programmes can be brought more into line with expectations, more functional and more qualitative.

The satisfaction of the student with his / her school is a perfect vehicle for assessing the impact of the university on the student [26]. Nursing schools which aim to provide quality nursing training can carry out work to make improvements in their schools with benefiting from the results of studies such as the measurement of the satisfaction and expectations of students, for this purpose [25].

Education is the process of creating a purposeful and desired change in the behaviour of an individual, through his / her own experiences. One of the concepts which is influential in this process is motivation [9]. Among the various factors which influence human behaviour motivation is the most important source of power which determines the direction and severity of the behaviour. Motivation holds an important place in studies on education - teaching which take on the function of shaping human behaviour $[1,12]$. The desire of nursing students to learn effectively and advance themselves or a significant portion of the issue which affect academic success can be explained by motivation.

Nursing training is a considerably stressful training from this point of view, and such a stressful training has a negative impact on the students. All of these reasons result in motivation among students decreasing. However, the motivation of students is extremely important for the development of skills such as learning and problem solving. Measures to increase the desire of students to learn are needed in order to be able to produce solutions to the issues faced in nursing training and raise the quality of education. The manner in which the factor of motivation, which is accepted as being one of the important elements influencing learning, constitutes an important issue. In order for this issue to be resolved, the structures which influence the motivation of students and create problems need to be determined first of all. Motivation is an important factor in the learning of an individual and the organisation of an atmosphere of learning [7].

Academic performance is expected to increase together with the satisfaction and motivation of students $[11,18]$. The increasing of quality in nursing training, the training of nurses who will perform their professions with a love for their occupation and a desire to work and ensuring student satisfaction and determining the source of the motivation and problems of students of nursing in order that solutions can be generated to the problems being faced, carries importance [9]. 
Culha, I., Kosgeroglu, N., Yılmaz, A.\& Unsal, A. (2016). Determination of the satisfaction and motivation levels in a group of nursing students, Global Journal on Advances in Pure \& Applied Sciences. [Online]. 2015, 07, pp 57-64. Available from: www.propaas.eu

\section{Material and Methods}

This is a descriptive study that was carried out between $10-24$ March 2014 with 97 students, who had medical surgical nursing subject in Eskisehir School of Health in Eskisehir Osmangazi University, agreed to take part in the study. The sampling method was not used in the study and it was aimed to reach the whole population.

A "Personal Information Form, Student Satisfaction Scale and Motivation Scale", prepared by making use of the literature which was appropriate for the subject of the study, were used as tools for collecting data in the study. Data was collected by the completing of survey forms prepared in advance, under supervision.

Personal Information Form is comprised of questions on certain socio-demographic characteristics, such as the age, gender, residence, type of family, whether they selected the department of their own free will, and whether they are satisfied with the department.

Student Satisfaction Scale was developed by Baykal, Sokmen and Korkmaz (2002) in order to determine the satisfaction levels of students studying in nursing schools, and was shortened and revised in 2011.The scale is comprised of 53 items and 5 sub-groups. The 53 items in the scale are assessed using a five point likert type scale of measurement. It has been determined that the scale is highly reliable, with its Cronbach's alpha value being 0,97 [3]. The Cronbach's alpha level of the scale during the study was found to be 0,95 .

Motivation Scale was developed by Acat and Kosgeroglu in 2006 with carrying out a validity and reliability study. The scale consists of a total of 24 questions and 3 sub-groups; intrinsic motivation,extrinsic motivation and negative motivation. The scale is a 5 point likert type scale. It is comprised of a total of 24 items, with 11 (items 1, 2, 3, 4, 6, 7, 8, 9, 10, 23, 24) directed at determining intrinsic motivation, 5 (items 13,14, 15, 17, 20) directed at determining extrinsic motivation and 8 (items 5, 11, 12, 16, 18, 19, 21, 22) directed at determining negative motivation. The items which constitute the negative motivation sub-group are scored in reverse. The score for each sub-group is determined by calculating the arithmetic mean of the relevant items within the sub-group, and the total score constitutes the level of motivation for professional learning of the individual. The higher the score achieved, the higher the level of motivation. The cronbach alpha value of the scale has been stated as being 0.82 [1], while the cronbach alpha value of the scale in the study was determined as 0.89 .

The data which was obtained was evaluated in the computer environment, using the IBM SPSS (version 21.0) statistics programme. The one way analyses of variance, student $t$ test and spearman correlation analysis were used in the analyses. The statistically significant level was accepted as being $\mathrm{p}<0.05$.

\section{Findings}

The ages of those who comprised the study group ranged from 19-25, with the mean being $20,05 \pm 1,08.84(86.6 \%)$ of the students were female and $13(13.4 \%)$ were male. The number of those who lived in Eskisehir city centre was 53 (54.6\%) and those who lived in student hostels was 59 (60.8\%). 87 (89.7\%) of the students were part of a nuclear family. 63 (63.9\%) had chosen the department of nursing of their own free will, and $69(71 \%)$ were satisfied with their department (Table 1).

Table 1. The scores achieved by the students in the satisfaction and motivation scale according to some of their 
Culha, I., Kosgeroglu, N., Yılmaz, A.\& Unsal, A. (2016). Determination of the satisfaction and motivation levels in a group of nursing students, Global Journal on Advances in Pure \& Applied Sciences. [Online]. 2015, 07, pp 57-64. Available from: www.propaas.eu

characteristics

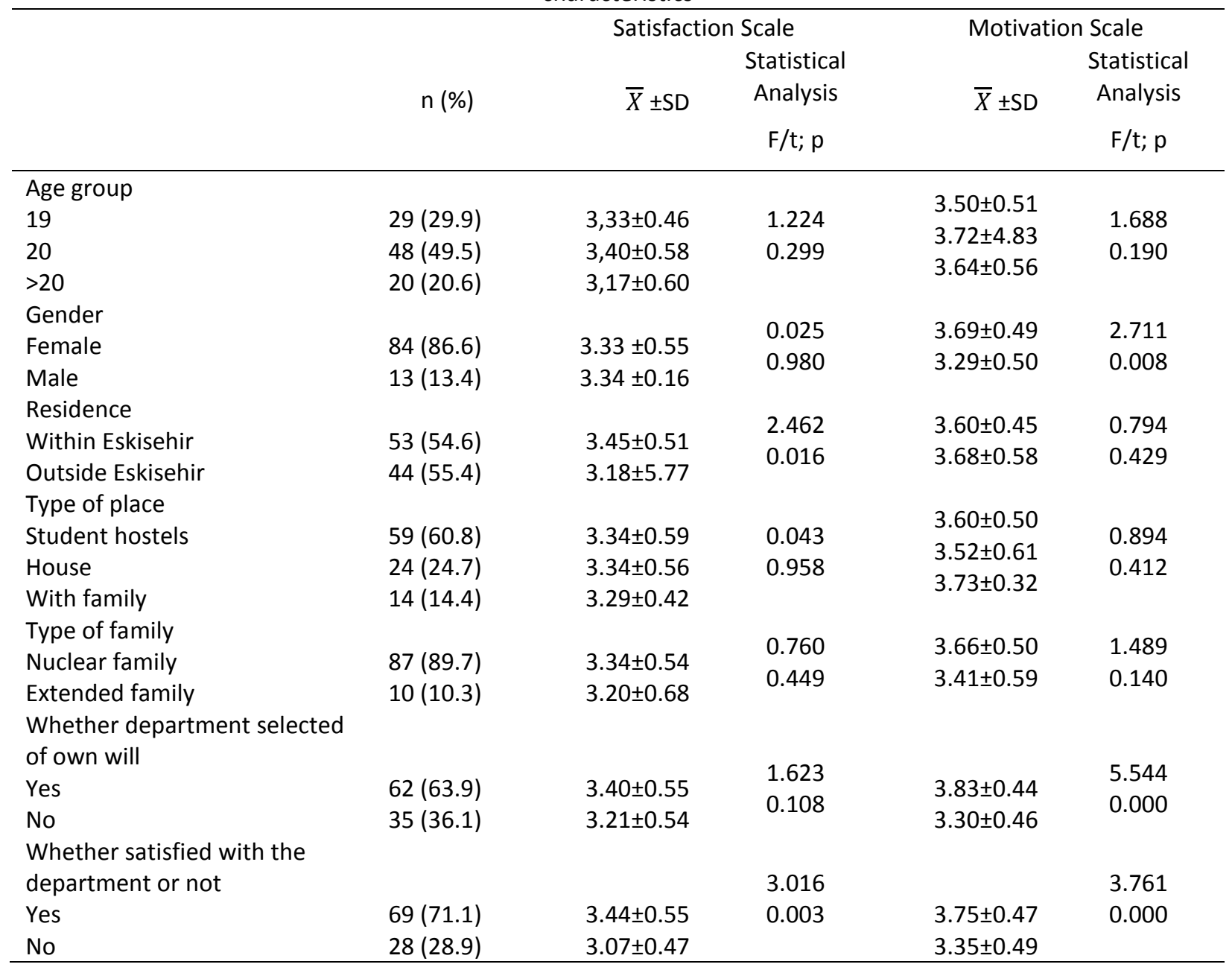

The scores obtained by the students from the satisfaction scale ranged between 1.72-4.64, with the mean being 3.33 \pm 0.55 (Table 2). It was determined that the scores of students who were satisfied with their department and who lived in Eskisehir city centre was higher $(p=0.003 ; p=0.016)$. No difference was found between age, gender, type of family and whether the department was selected of the student's own free will and the scores obtained from the satisfaction scale ( $p>0.05$ for each one) (Table 1).

The scores obtained by the students from the motivation scale ranged between 2.07-4.97, with the mean being 3.73 \pm 0.52 . It was determined that the mean scores of the students in the motivation scale were $3.67 \pm 0.67$ from the intrinsic motivation sub-group, $4.17 \pm 0.60$ from the extrinsic motivation subgroup and $3.26 \pm 0.63$ from the negative motivation sub-group (Table 3 ). Significant differences were found between gender, whether the department was chosen of the student's own free will and satisfaction from the department and the scores obtained from the motivation scale $(p=0.008$; $p=0.000 ; p=0.000$ respectively) (Table 1 ). A positive and significant relationship was found between the satisfaction scale of the students and the scores they obtained from the motivation scale $(r=0.241$; $\mathrm{p}=0.017)$. 
Culha, I., Kosgeroglu, N., Yılmaz, A.\& Unsal, A. (2016). Determination of the satisfaction and motivation levels in a group of nursing students,Global Journal on Advances in Pure \& Applied Sciences. [Online]. 2015, 07, pp 57-64. Available from: www.propaas.eu

\begin{tabular}{lcc}
\hline Sub-groups & Min-Max & $\bar{X} \pm$ SD \\
\hline Instructor & $1.92-5.00$ & $3.68 \pm 0.53$ \\
School administration & $1.78-5.00$ & $3.43 \pm 0.70$ \\
Participation in decisions & $1.14-5.00$ & $3.20 \pm 0.82$ \\
Scientific, social and technical facilities & $1.25-4.50$ & $2.99 \pm 0.66$ \\
Education and teaching attiribute & $1.23-4.69$ & $3.32 \pm 0.66$ \\
Total & - & $3.33 \pm 0.55$ \\
\hline
\end{tabular}

Table 3. The scores achieved by the students in the motivation scale

\begin{tabular}{lcc}
\hline Sub-groups & Min-Max & $\bar{X} \pm$ SD \\
\hline Intrinsic motivation & $1.91-5.00$ & $3.67 \pm 0.67$ \\
Extrinsic motivation & $1.40-5.00$ & $4.17 \pm 0.60$ \\
Negative motivation & $1.25-5.00$ & $3.26 \pm 0.63$ \\
Total & - & $3.73 \pm 0.52$ \\
\hline
\end{tabular}

\section{Discussion}

Precautions are required to increase the desire of students to learn and become distinct in order to be able to generate solutions to the problems being experienced in nursing training and raise the quality of education [1]. The levels of satisfaction and motivation are important factors which have an impact on learning and teaching [2] and may influence the academic performance of the students $[11,18]$. With this in mind, the study has attempted to determine the satisfaction and motivation scores of a group of nursing students, as well as the relationship between these two scores.

Low satisfaction levels have been found in nursing students in studies conducted previously $[4,10,13,15]$. In our study the satisfaction levels of the students was at a medium level, and when their sub-group scores were examined the lowest scores were found in the area of scientific, social and technical facilities, and the highest scores were found in the area of instructor. As a result, it can be said that the students found the school to be positive in respect of the instructor, but that they found it insufficient in terms of the other facilities. It is necessary under these circumstances to determine the wishes and expectations of the students in order to improve the services within the school. Karadag et al (2012) and Yangın and Kırca (2013) found a level of satisfaction close to that within our study [14,27]. In contrast to our study, Karadag et al (2012) found the lowest level of satisfaction in the instructor sub-group [14] while in the study by Yangın and Kırca (2013), the highest level of satisfaction was found in the sub-groups of the instructor, education and teaching attiribute, and is similar to our study in this respect [27]. In the study carried out by Butt and Rehman (2010) on the satisfaction levels of students in higher education, it was determined that instructor possess the highest influence on the level of satisfaction of students [6].

The discovery of higher satisfaction scores among students who are satisfied with their departments in the study is an expected outcome. The findings of Bilgin and Ocakcl (2011) support our study [5]. The high satisfaction scores of those who live in Eskisehir, on the other hand, can be interpreted as students being affected by the environment in which they live as well as their educational areas.

A high level of motivation is important in respect of the desire to learn and the embracing of the profession [5]. The motivation of the students in our study were found to be at medium levels. When the motivation sub-groups are examined it can be seen that extrinsic levels of motivation are higher than intrinsic levels. According to Khalaila (2015), intrinsic motivation is related to academic success [16]. Under these circumstances the support of initiatives which ensure the intrinsic motivation of students carries importance. When studies directed at the area within our country are assessed, while 
there are other studies which have also found the extrinsic motivation levels of students to be higher than their levels of intrinsic motivation $[14,20]$ there are also studies which have found contradicting outcomes than our study $[7,9,21,22]$. While the negative motivation score was found to be the lowest sub-group motivation score within our study, Ozlu et al (2014) found the negative motivation subgroup score to be the highest. However, there are also other studies which do support our findings $[7,14,20,21]$.

There is a relationship between the positive opinions of students towards their professions and departments and their levels of professional motivation. As is expected, the motivation levels of those who are satisfied with their department and who had chosen it of their own free will was determined to be higher in our study. The fact that more than half $(63.9 \%)$ of students within the study selected their department of their own free will and again that more than half are satisfied with their department (71.1\%), also supports the high level of professional motivation. In their study, Ozkan and Yılmaz (2009) determined the motivation levels of students who stated that they were satisfied with their department to be higher, and this is consistent with our study [21].

In our study, the professional motivation levels of female students is higher than those of male students, and a significant difference has been found between them. It is believed that the reason for this is that the profession is perceived more as one which is more appropriate for women. Similarly, Celik (2014) and Ozkan and Yilmaz (2009) have also reported higher levels of motivation among female students [7,21], while Civic and Sener (2012), Gayef and Sarıkaya (2012), and Ozlu et al. (2014) do not report any difference between the genders in terms of motivation levels, in contrast to our study $[9,12,22]$.

Our study has also found that as the satisfaction levels of students increase so did their motivation levels, and the findings of Karadag et al (2012) also support our study [14]. Motivation and satisfaction are related and are effective concepts in learning [1]. It is reported that the learning environment and the relationship between students and instructor has an impact on the satisfaction and motivational status of students $[11,17,18]$. In this context, it will be possible for students to reach the required levels of motivation and satisfaction by determining the shortcomings and making the necessary arrangements in these areas.

\section{Results and Suggestions}

It has been determined that the satisfaction of students is influenced by their residence and satisfaction from the department, and that there is a relationship between the satisfaction and motivation levels of students. The satisfaction and motivation levels of students in educational institutions need to be measured regularly, and arrangements and improvements need to be made in the required areas.

As well as the theoretical knowledge provided in the courses within the process of education, importance needs to be placed on projects and practical work which will enable students to recognise their own skills, in order to increase the motivation of nursing students and their positive motivation directed at the profession. The areas of work after their graduation need to be presented to student nurses in order to assist in determining their positive objectives for the profession.

\section{References}

[1]Acat, B., \& Kosgeroglu, N. (2006). Gudulenme kaynakları ve sorunları olcegi. Anadolu Psikiyatri Dergisi, 7, 204210.

[2]Ansari ve Oskrochi (2006). What matters most? Predictors of student satisfaction in public health educational courses. Public health, 120(5), 462-473. 
[3]Baykal, U., Harmanci, A.K., Eskin, F., Altuntas, S., \& Sokmen, S. (2011). Ogrenci doyum olcegi, kisa form gecerlik- guvenirlik calismasi. Anadolu Hemsirelik ve Saglık Bilimleri Dergisi, 14(4), 60-68.

[4] Baykal, U., Sokmen, S., Korkmaz, S., \& Akgun, E. (2005). Determining student satisfaction in a nursing college. Nurse Education Today, 25(4), 255-262.

[5] Bilgin, Z., \&Ocakcı, F. A. (2011). Ebelik ogrencilerinde gudulenme. Journal of Anatolia Nursing and Health Sciences, 14(3).

[6] Butt, B. Z., \& Rehman, K. (2010). A study examining the students satisfaction in higher education. ProcediaSocial and Behavioral Sciences, 2(2), 5446-5450.

[7]Celik, S. (2014). Hemsirelik ogrencilerinin mesleki gudulenme duzeyleri ve etkileyen faktorler. Saglik Bilimleri ve Meslekleri Dergisi, 1(2), 43-56.

[8]Chiandotto, B., Bini, M., \& Bertaccini, B. (2007). Quality assessment of the university educational process: An application of the ecsı model. Effectiveness of university education in Italy: Employability, competences. human capital (Ed. Fabbris, L.). Physica-Verlag A Springer Company. 43-57.

[9]Civci, H., \& Sener, E. (2012). Hemsire adaylarının mesleki gudulenme duzeyleri ve etkileyen faktorlerin belirlenmesi. DEUHYO ED,5(4), 142-149.

[10]Egelioglu, N., Arslan, S., \& Bakan, G. (2011). Hemsirelik ogrencilerinin memnuniyet durumlarinin akademik basarilariuzerine etkisi. Hemsirelikte Arastirma Gelistirme Dergisi, 1, 14-24.

[11]Filak, V. F., \& Sheldon, K. M. (2008). Teacher support, student motivation, student need satisfaction, and college teacher course evaluations: Testing a sequential path model. Educational Psychology, 28(6), 711724.

[12]Gayef, A., \& Sarıkaya, O. (2012). Saglık hizmetleri meslek yuksekokulu ogrencilerinde mesleki gudulenme. Tıp Egitimi Dunyası Dergisi, 33, 9-18.

[13]Hakım, A. (2014). Nursing students' satisfaction about their field of study. Journal of Advances in Medical Education \& Professionalism, 2(2), 82.

[14]Karadag, E., Acıkgoz, A., Alparslan, G. B., Unsal, A., Kosgeroglu, N., Kaya, Y., Guven, B., \& Yilmaz, A. (2012). Association between students' satisfaction and motivation in nursery and midwifery education. HealthMED, 6(12), 4210-4216.

[15]Kaynar, A., Sahin, A., Bayrak, D., Karakoc, G., Ulke, F., \& Ozturk, H. (2010).Karadeniz Teknik Universitesi Trabzon Saglık Yuksekokulu hemsirelik ogrencilerinin doyum duzeyleri. C.U. Hemsirelik Yuksekokulu Dergisi,10(3),12-19.

[16]Khalaila, R. (2015). The relationship between academic self- 
Culha, I., Kosgeroglu, N., Yılmaz, A.\& Unsal, A. (2016). Determination of the satisfaction and motivation levels in a group of nursing students, Global Journal on Advances in Pure \& Applied Sciences. [Online]. 2015, 07, pp 57-64. Available from: www.propaas.eu

[24]Scott, P. (2002). Kuresellesme ve universite: 21. yuzyılın onundeki meydan okumalar. Kuram ve Uygulamada Egitim Bilimleri,2(1), 193-208.

[25]Soylemez, D., Sur, H., \& Cebeci, D. (2005). Hemsirelerin is doyumu ile ilgili bir meta analizi calısması. Hastane Yonetimi,34-41.

[26] Umbach, P.D., \& Porter, S.R. (2002). How do academic departments impact student satisfaction?: Understanding the contextual effects of departments. Research in Higher Education,43(2), 209-234.

[27]Yangın, H. B., \& Kırca, N. (2013). Antalya Saglık Yuksekokulu hemsirelik ogrencilerinin memnuniyet duzeyleri ve etkileyen faktorler. Gumushane Universitesi Saglık Bilimleri Dergisi, 2(1). 